\title{
EXAMINATION OF CAP SCREWS \\ FROM CURRENCY PRINTING PRESS \\ FLANGES
}

T. Robert Shives

Mechanical Properties Section

Metallurgy Division

Institute for Materials Research

National Bureau of Standards

Washington, D.C. 20234

Failure Analysis Report

June 1977

Prepared for

Office of Engineering

Bureau of Engraving and Printing

Department of the Treasury

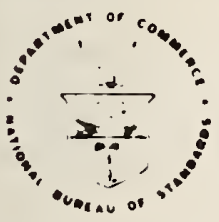

U.S. DEPARTMENT OF COMMERCE, Juanita M. Kreps, Secretary

Dr. Sidney Harman. Under Secretary

Jordan J. Baruch. Assistant Secretary for Science and Technology

NATIONAL BUREAU OF STANDARDS, Ernest Ambler, Acting Director 

SUMMARY iii

1. InTRODUCTION................................. 1

1.1 Reference................................ 1

1.2 Parts Submitted............................. 1

2. PURPOSE..................................... 2

3. RESULTS OF EXAMINATIONS, TESTS, AND ANALYSES............. 2

3.1 Fractographic Examination....................... 2

3.2 Chemical Composition........................ 3

3.3 Dimensional Measurements....................... 3

3.4 Hardness Measurements.......................... 4

3.5 Metallographic Examination..................... 4

4. DISCUSSTON................................. 5

4.1 Dynamic Loading on Loose Screws.................... 5

4.2 Tensile Strengths Inferred from Hardness............... 6

4.3 Metallographic Observations...................... 7

5. CONCLUSIONS ................................ 8

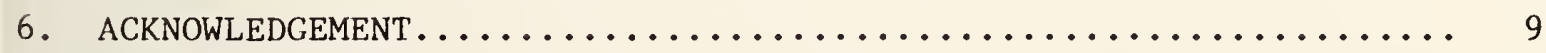

TABLES

1. Results of Chemical Analyses of Cap Screws................ 10

2. Results of Dimensional Measurements of Stretched Type A Cap Screw................................. 11

3. Results of Surface Hardness Measurements on Cap Screws......... 12

4. Results of Hardness Traverses through Longitudinal Sections of Cap Screws............................. 13 


\section{FIGURES}

1. Fracture surface of type A cap screw.

2. Fracture surface of type A cap screw.

3. SEM fractograph of the fatigue portion of the fracture in type A cap screw.

4. SEM fractograph of the fatigue portion of the fracture in type A cap screw.

5. Longitudinal sections through two type A cap screws.

6. Longitudinal sections through two cap screws.

7. Deeply etched longitudinal section through cap of fractured type A cap screw showing the fracture profile.

8. Part of the longitudinal section shown in figure 7 .

9. Unetched longitudinal section through type A cap screw exhibiting an inclusion content representative of the cap screws examined.

10. Longitudinal section through type $C$ cap screw showing part of one thread.

11. Longitudinal section through type C cap screw exhibiting representative microstructure which consists primarily of tempered martensite.

12. Longitudinal section through an unstretched type A cap screw exhibiting microstructure which consists primarily of tempered martensite.

13. Longitudinal section through stretched type A cap screw. 
The Office of Engineering of the Bureau of Engraving and Printing submitted a number of failed and intact cap screws from printing press flanges to the NBS Mechanical Properties Section for examination. All of the cap screw failures examined were due to the initiation and propagation of fatigue cracks. Based on the results of hardness measurements, some of the cap screws of one manufacturer did not meet the minimum ultimate tensile strength requirements for DIN 12.9 screws. One cap screw with an ultimate tensile strength significantly below the specified minimum had yielded apparently while in service. 

Examination of Cap Screws from Currency Printing Press Flanges

\section{INTRODUCTION}

\subsection{Reference}

This examination was requested by Mr. Milton J. Seidel, Chief, Office of Engineering, Bureau of Engraving and Printing, in a letter to Dr. Bruce W. Christ, Chief, NBS Mechanical Properties Section. The request was dated May 26, 1976.

\subsection{Parts Submitted}

Over a period of months, the office of Engineering of the Bureau of Engraving and Printing submitted several groups of cap screws from currency printing press flanges to the NBS Mechanical Properties Section for examination. Cap screw types A, B, C, and D had a nominal diameter of $24 \mathrm{~mm}$ and a pitch of $3 \mathrm{~mm}$. Type E had a nominal diameter of about $35 \mathrm{~mm}$ and a pitch of about $4 \mathrm{~mm}$. The cap screws are used to fasten flanges to cylinders on currency printing presses. The caps of the screws fit into counterbores in the flanges. The cylinders on the printing presses rotate at $34 \mathrm{rpm}$ on the Giori presses and $67 \mathrm{rpm}$ on the American Bank Note presses.

The various groups of submitted cap screws are listed below:

A. May 26, 1976
a. One failed type A cap screw from American Bank Note printing press no. 304.
b. One new cap screw to be used on an American Bank Note printing press.

B. July 15,1976
a. One new type A cap screw.
b. Three new type $C$ cap screws.
c. One threaded shank from a failed type C cap screw.
d. One new type E cap screw (type used on the Giori-80 printing presses).
e. One new type D cap screw.

C. July 19,1976

a. Six failed type A cap screws -- caps only. 
b. One failed type B cap screw -- cap only -- from impression cylinder.

D. September 9, 1976

a. Seven failed type D cap screws from Giori-74 printing press (no. 202).

b. Three intact type A cap screws from Giori-74 printing press (no. 202).

E. October 7, 1976

a. One intact type E cap screw.

b. Two used, intact type A cap screws labeled $\mathrm{H}$ and Q, respectively.

c. One apparently unused type A cap screw.

\section{PURPOSE}

The Office of Engineering of the Bureau of Engraving and Printing requested that the NBS Mechanical Properties Section examine the submitted cap screws in order to determine the nature of the failures.

\section{RESULTS OF EXAMINATIONS, TESTS, AND ANALYSES}

\subsection{Fractographic Examination}

The fracture surfaces of all of the failed cap screws were examined visually and macroscopically. Selected samples were examined with the scanning electron microscope (SEM). All of the fractures appeared to have initiated in fatigue. Actually, in each fracture, a number of fatigue cracks had initiated adjacent to each other, but on slightly different transverse planes. After propagating a relatively short distance, the several fatigue cracks joined to form a common crack front. This common crack front then propagated in fatigue transversely across the cap screw until the cross section had been reduced sufficiently so that it could no longer support the applied load and fracture was completed in ductile overload.

In some of the fractures, fatigue cracks initiated in two regions about $180^{\circ}$ apart. When this phenomenon occurred, there were two crack fronts that propagated toward each other. As in the case of the single crack front, fracture was completed in ductile overload when the cross section of the cap screw was reduced sufficiently so that it could no longer support the applied load. 
Cracks initiated in either of two locations in the cap screws -just under the cap or through the root of one of the threads, depending when in a sequence of failures a particular screw failed. A larger portion of the fracture of the screws that were among the first to fail in a sequence of failures propagated in fatigue compared to the fractures of the screws that failed later in the sequence. Examples of the fracture surfaces and fracture profiles of cap screws at two different stages of the fracture sequence are shown in figures 1 and 2 .

Representative fracture surfaces were examined with the scanning electron microscope (SEM). Examples of the features exhibited by the fatigue portion of the fractures are shown in figures 3 and 4 . There is no evidence of fatigue striations in figure 3, but some apparent striations can be seen in figure 4. Fatigue striations are often not resolvable in steel fractures. Dimpled rupture is the fracture mode in the overload portion of the fracture.

\section{2 Chemical Composition}

A sample from one cap screw from each of three different manufacturers was submitted to a commercial laboratory for chemical analysis. The results of these analyses are presented in Table 1 . The type $A$ and type C cap screws were fabricated from AISI 8630 and 4140 steels, respectively. The type D cap screws were fabricated from a steel similar in composition to the AISI 5100 series. The chemical composition of the types $B$ and $D$ cap screws was not determined.

\subsection{Dimensional Measurements}

One of the type A cap screws that had been used, but was still intact appeared to have been deformed by being stretched over a distance of several threads. Longitudinal sections through this cap screw and through another type A cap screw that did not appear to exhibit any macroscopic deformation are shown in figure 5. The approximate region of stretch in the deformed cap screw is indicated in figure $5 \mathrm{a}$ by brackets. The pitch and minor diameter were determined along the length of a longitudinal section through the stretched screw. The section was not through the longitudinal axis of the screw; therefore the minor diameter measurements do not represent the true minor diameter, but they do show differences caused by the stretching. The results of these measurements are presented in Table 2. A way from the region of deformation, the pitch averaged $3.00 \mathrm{~mm}$. Where the deformation was severe -- at the third thread from the cap -- the pitch rose to a maximum of $3.81 \mathrm{~mm} \mathrm{--}$ about $27 \%$ above the average. At this same location, the minor diameter was $18.42 \mathrm{~mm}$ compared to $19.91 \mathrm{~mm}$ away from the region of deformation. This cap screw had apparently been stressed beyond its yield point. 


\subsection{Hardness Measurements}

Rockwell hardness measurements were made at various locations on most of the as-received cap screws. The range of hardness and the number of screws for which the hardness was determined at any given location are presented in Table 3. Excluding the type $B$ and the type E cap screws tested, there were some variations in hardness both among and within the three other groups of cap screws -- types A, C, and D. The variation was least among the three groups at the bottom of the screws. The hardness data for the stretched type A cap screw are 1 isted separately at the bottom of Table 3. This screw is softer than the other type A screws, the type C screws, and the type D screws at each location where measurements were taken, and it was significantly softer at the shank adjacent to the cap at the bottom of the screw.

In addition to the hardness measurements on the as-received screws, HRC hardness traverses were made on longitudinal sections through the stretched type A cap screw, the undeformed type A cap screw shown in figure 5, one type $C$ cap screw, and one type D cap screw. The hardness measurements were made near the longitudinal axes of the screws. The results of these traverses are presented in Table 4. The types $C$ and D cap screws were very similar in hardness, whereas the unstretched type A cap screw was significantly softer over the entire length. The stretched type A cap screw was similar in hardness to the unstretched type A cap screw at the top, but it was significantly softer away from the top.

\subsection{Metallographic Examination}

Longitudinal sections were taken through two type A cap screws, one type C cap screw, and one type D cap screw. The sections through the two type A cap screws are shown in figure 5. The other sections are shown in figure 6. All four sections were heavily etched when photographed for figures 5 and 6 in order to reveal flow line patterns. Although there were obvious differences in the flow line patterns among the different specimens, nothing unexpected was observed.

A longitudinal section through one of the fractured type A cap screws showing the fracture profile appears in figure 7. This section has been heavily etched to reveal the flow line patterns. In this fracture, fatigue cracks initiated just under the cap, and they initiated in two general regions approximately $180^{\circ}$ apart. These two regions are indicated by arrows 0 in figure 7. The crack front that initiated at the left in the figure deviated from the primary fracture where the two advancing crack fronts meet and followed the path indicated by the unmarked arrows. For a large part of this path, the crack followed the flow lines. 
There were a number of relatively short secondary cracks that were essentially parallel to the fracture and slightly removed from it. Two such cracks appear in figure 8 which shows part of the longitudinal section that appears in figure 7 , but at higher magnification. The approximate location of these cracks is indicated by arrow C in figure 7 . These cracks initiated in the fillet between the shank and the cap of the screw. The surface of the cap screw at the fillet appears to be rather rough, possibly due to machine tool marks. Surface roughness creates stress concentrations that increase the ease with which a fatigue crack can initiate.

Sections of cap screws of some of the types were also examined microscopically. For the cap screws examined, the material in the type A, type $C$, and type $D$ cap screws was very similar in regard to inclusion content. A field showing a representative inclusion content appears in figure 9. In general, the inclusion content was not considered abnormally high, although one high inclusion region was found near the center of the cap of one of the type A cap screws. The low inclusion content is consistent with the low sulfur and phosphorus indicated by the chemical analyses.

The type $C$ cap screw section exhibited longitudinal crevices adjacent to the surface over the entire length of the screw. Apparently the cap screw had been subjected to a surface treatment that had attacked the "stringer" inclusions as well as the surrounding material to produce the condition shown in figure 10 .

The microstructure of all of the cap screws examined consisted primarily of tempered martensite. Photomicrographs showing fields representative of the type $C$ cap screw and the undeformed type A cap screw appear in figures 11 and 12, respectively. The microstructure of the type D cap screw was similar to that of the type A cap screw shown in figure 11. The microstructure of the stretched type A cap screw is shown in figure 13. Although this microstructure consists primarily of tempered martensite, it is different from the others in that banding is evident.

The microstructure of types B and E cap screws was not examined.

\section{DISCUSSION}

\subsection{Dynamic Loading on Loose Screws}

The cap screw failures examined in this task were caused by the initiation and propagation of fatigue cracks due to high cyclic stresses developed as the cylinder rotates. Cracks initiated either just under the cap or at the root of a thread. A plausible explanation for the difference in location of the initiation sites was offered by Mr. Francis R. Varrese, Manager of Materials Research, Standard Pressed Steel Company, Jenkintown, Pennsylvania. It was his opinion -- and we 
concur with that opinion -- that when a number of screws in one flange fail over a period of time and are not replaced, fatigue cracks would probably initiate under the screw cap in the screws that fail first. After several screws have failed, those remaining would be more likely to develop fatigue cracks initiating at the root of a thread. The change in location of the initiation sites is due to the development of higher bending stresses in the screws that fail later in the sequence. The higher bending stresses would be developed partly because there would be fewer screws remaining to support the applied load and partly because of a lack of symmetry in the support system caused by the loss of some of the screws.

The increase in the proportion of fatigue fracture to overload fracture in the screws that fail last is due to the higher stress amplitude in the screws that fail last compared to those that fail early in the sequence. Again, the higher stress amplitude is caused by fewer screws supporting the applied load.

As indicated in an earlier memorandum ${ }^{1}$, inadequate torquing leads to increased repeated dynamic loading of the screws during rotation of the cylinder and flange. Such loading can lead to fatigue crack initiation. Careful attention to proper torquing of the cap screws should decrease the probability of fatigue failure. In addition, it is important that there be proper clearance between the fillet at the base of the screw cap and the bottom of the counterbore in the flange. Improper clearance may lead to high stress concentrations, stress relaxation, and subsequent loosening of the cap screws -- with an accompanying increase in the dynamic load. A smoother finish on the fillet at the base of the screw cap would also help to reduce stress concentrations in this region.

\subsection{Tensile Strengths Inferred from Hardness}

According to the type A cap screw manufacturer's pamphlet, the minimum and maximum allowable ultimate tensile strength for a DIN 12.9 screw is 174,000 and 203,000 psi, respectively. It also states that the type A cap screws are manufactured with a minimum ultimate tensile strength of between 186,000 and 189,000 psi.

Manufacturer's information for the types C and D cap screws indicate that the minimum and maximum allowable ultimate tensile strength for the DIN 12.9 cap screws is 170,000 and 200,000 psi, respectively. The approximate equivalent HRC hardness values for the tensile strengths are as follows:

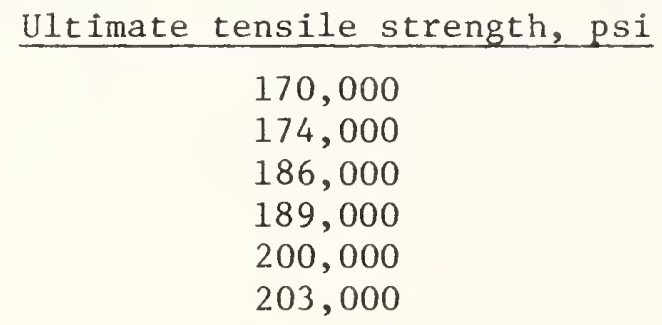

Hardness, HRC 
The results of the hardness traverses on the longitudinal sections through both the type $\mathrm{C}$ and type $\mathrm{D}$ cap screws convert to approximate tensile strengths of 182,000 and 194,000 psi, respectively. Both of these tensile strength values are well within the allowable tensile strength range. Hardness measurements on the as-received type D screws also indicate tensile strengths within the specified range with the possible exception of one measurement. This one measurement (37 HRC), however, converts to a tensile strength just below the minimum acceptable in the specification. Since the conversion of hardness data to tensile strength is only approximate, it can not be said with any degree of certainty that this measurement is outside of specifications.

Several of the hardness measurements on the as-received type $C$ cap screws converted to tensile strengths below 170,000 psi. These low values may be at least partially explained by the regions at the surface where stringers and the material surrounding them had been attacked.

All of the values from the hardness traverse on the unstretched type A cap screw, and many of the hardness values from the as-received type A screws were approximately equivalent to tensile strengths below 170,000 psi. Therefore, the tensile strength of many of the examined type A screws appears to be lower than the specification allows.

Both the as-received hardness values and the hardness traverse values from the stretched type A cap screw converted to ultimate tensile strength values significantly below the specified minimum. In fact, the hardness traverse values were approximately equivalent to ultimate tensile strength values ranging from 96,000 to 132,000 psi.

The ultimate tensile strength of the type B cap screw as determined from hardness measurements on the as-received screws ranged from about 126,000 to 129,000 psi. These values are within the DIN specified limits of 116,000 to $145,000 \mathrm{psi}$. These limiting values were taken from the manufacturer's literature.

\subsection{Metallographic Observations}

The microstructures of the unstretched type $A$, the type $C$, and the type D cap screws that were examined consisted of tempered martensite and appeared to be satisfactory. There were regions at the surface of the type $C$ screws where stringer inclusions and the material surrounding the stringers had been attacked and eaten out. These regions could act as stress concentrators, but since their major dimension is longitudinal, they would not likely be sources of transverse fatigue cracks. Indeed, there is no evidence to indicate that these regions contributed to the fatigue failures.

The microstructure of the stretched type A cap screw also consisted of tempered martensite, but there was banding in evidence which is undesirable. Since this screw also exhibited abnormally low hardness, 
and consequently low strength, it apparently was not properly heat treated. The unusually low strength is probably what allowed the screw to yield in service.

The inclusion content of all the cap screws examined was similar and was not considered to be abnormally high.

Nothing abnormal was observed regarding the forging flow line pattern. Even though one secondary crack was observed to have followed the forging flow line pattern, in general, the fracture paths did not appear to be influenced by these flow lines.

There were significant differences among the chemical compositions of the screws from different manufacturers. Chemical composition, however, is not believed to have contributed to any of the failures.

\section{CONCLUSIONS}

1. All of the failed cap screws appeared to have failed due to the initiation and propagation of fatigue cracks.

2. Fatigue cracks initiated either just below the cap of the screw or at the root of a thread, depending on the position of a given cap screw in a sequence of failures in one flange.

3. Based on hardness measurements, some of the type A cap screws appeared to have ultimate tensile strengths below the specified minimum. One type A cap screw had an ultimate tensile strength significantly below the specified minimum.

4. Based on hardness measurements, the ultimate tensile strength of the types $B$ and $D$ cap screws appears to meet specifications.

5. Hardness measurements on the as-received cap screws indicated that the ultimate tensile strength of some of the examined type $C$ cap screws is below the specified minimum. Hardness measurements on a longitudinal section through a type $\mathrm{C}$ cap screw indicated that the ultimate tensile strength is satisfactory. The low hardness values on the as-received screws may be due to the stringers and surrounding material having been attacked.

6. The low hardness-low strength type A cap screw had yielded apparently while in service.

7. The microstructure of the cap screws examined appeared to be satisfactory except for the banding in the low strength type A cap screw. 


\section{ACKNOWLEDGEMENT}

The hardness tests and the metallography were performed by Leonard C. Smith of the NBS Mechanical Properties Section. The photographic work was performed by Mr. Smith and Todd Eudy, also of the NBS Mechanical Properties Section. 


\section{Table 1. Results of Chemical Analyses of Cap Screws}

Element

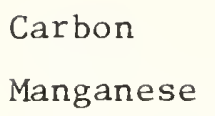

Phosphorus

Sulfur

Silicon

Nickel

Chromium

Molybdenum

Copper
Type A

$0.33 \%$

0.91

0.014

0.012

0.30

0.52

0.50

0.21

0.16
Cap Screw

Type C

Type D

$0.41 \%$

$0.43 \%$

0.71

0.024

0.012

$<0.005$

0.31

0.19

0.97

0.03

0.20 
Table 2. Results of Dimensional Measurements of Stretched Type A cap screw

$\begin{array}{ccc}\text { Thread } & \text { Minor Diameter, mm } & \text { Pitch, mm } \\ 1 & 19.40 & 3.35 \\ 2 & 18.85 & 3.33 \\ 3 & 18.42 & 3.81 \\ 4 & 18.97 & 3.10 \\ 5 & 19.35 & 3.07 \\ 6 & 19.61 & 3.12 \\ 7 & 19.81 & 3.00 \\ 8 & 19.91 & 3.05 \\ 9 & 19.91 & 3.00 \\ 10 & 19.94 & 3.00 \\ 11 & 19.91 & 2.97 \\ 12 & 19.86 & 3.02 \\ 13 & 19.99 & 3.02 \\ 14 & 19.96 & 3.00 \\ 15 & 19.91 & 3.00 \\ 16 & & \end{array}$




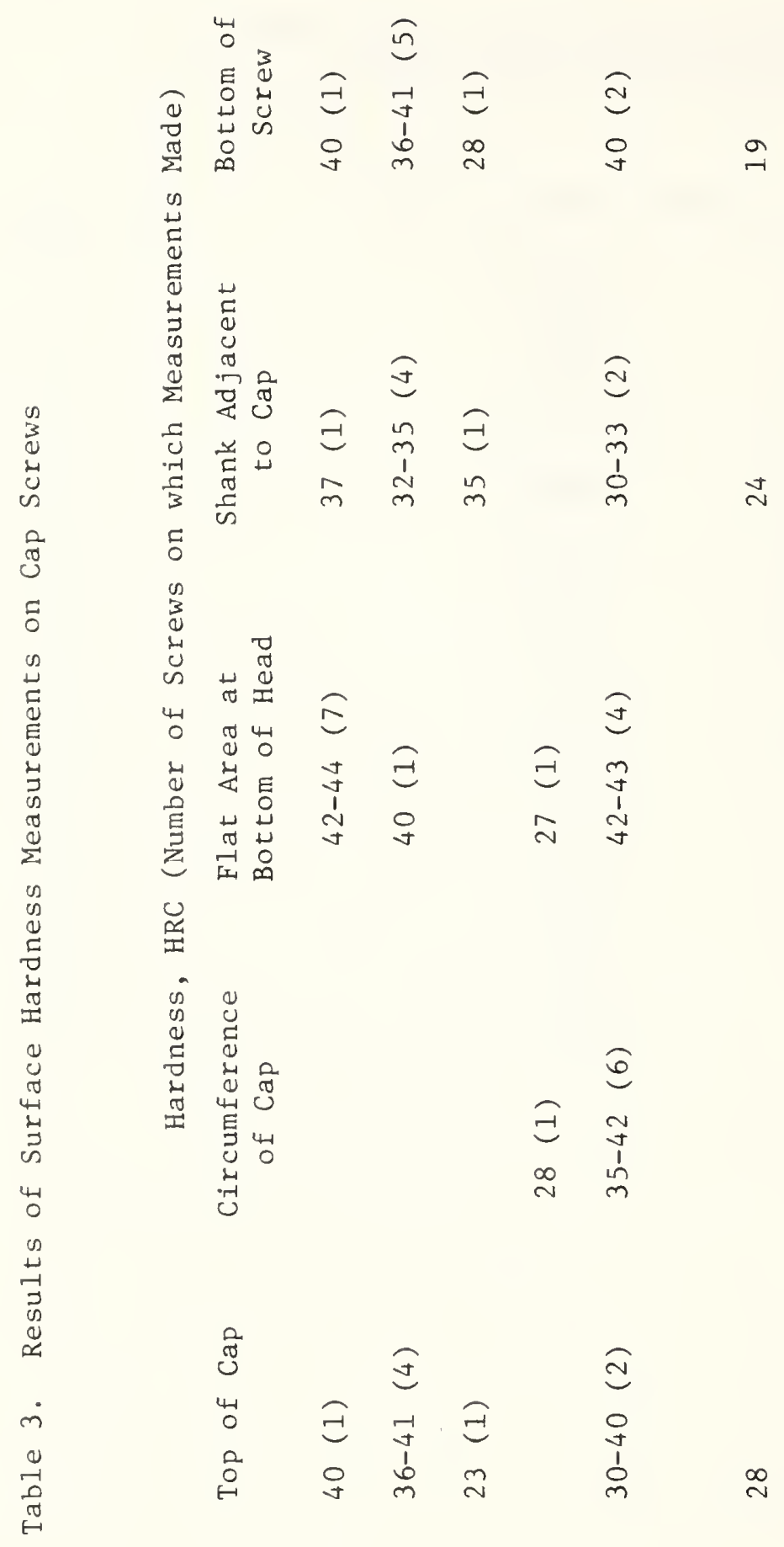

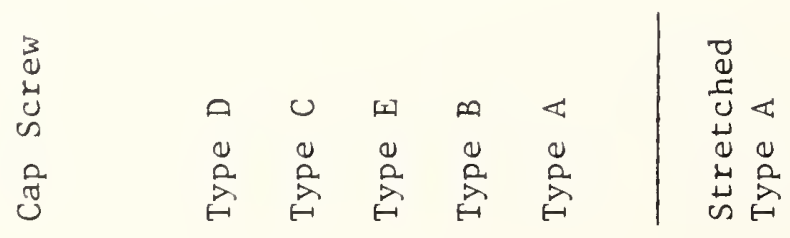




$$
\begin{aligned}
& \text { 重 }
\end{aligned}
$$

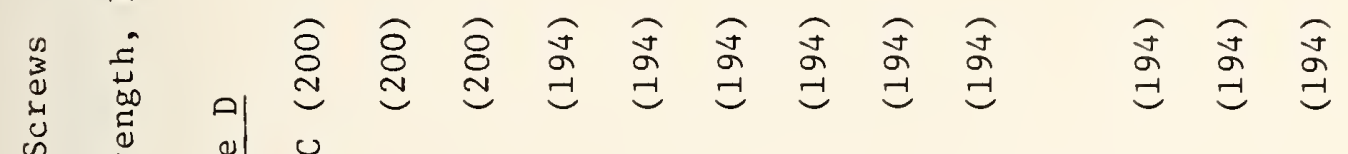

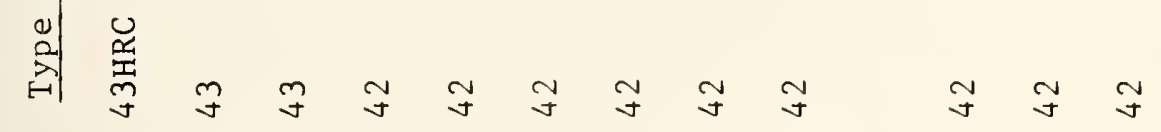

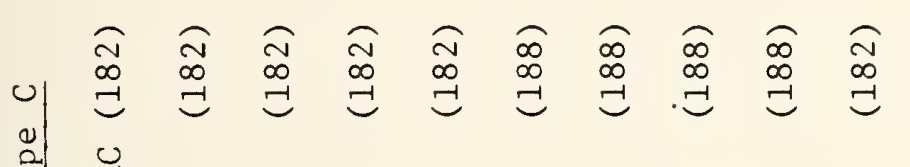

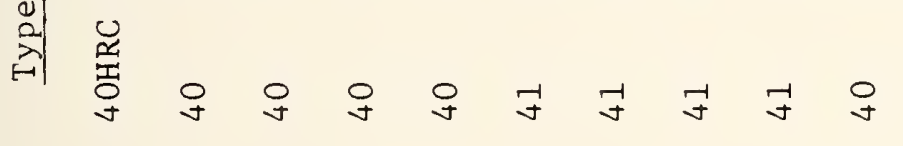

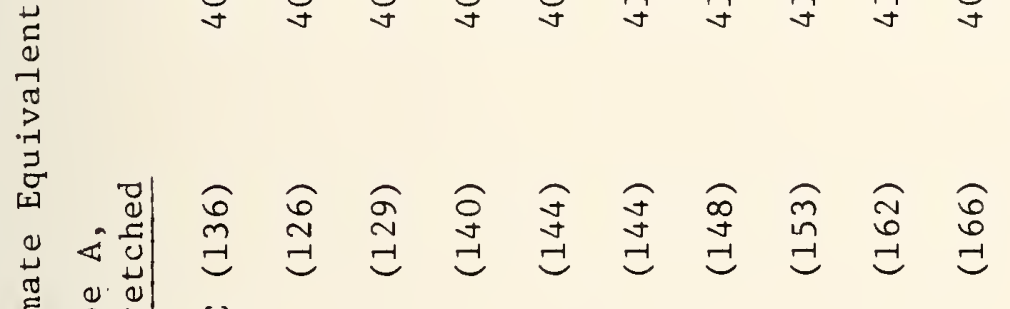

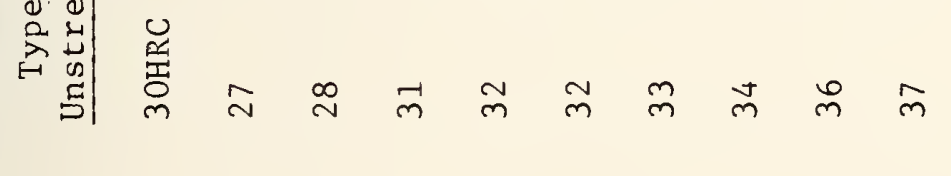

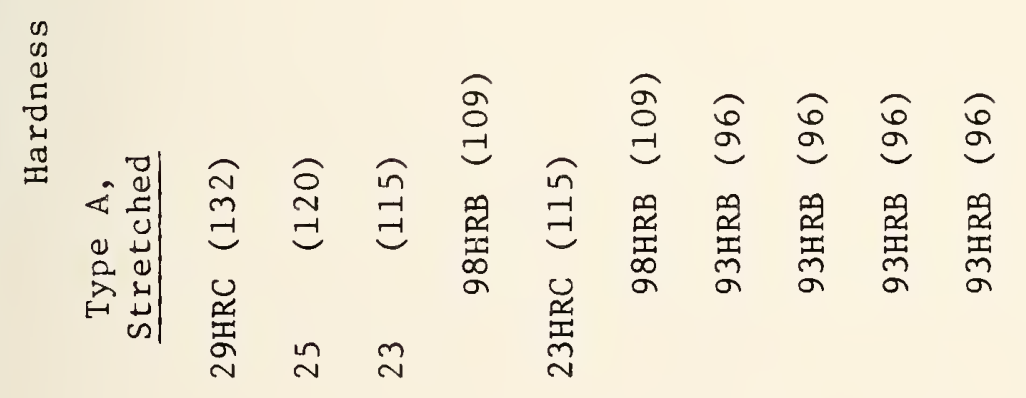

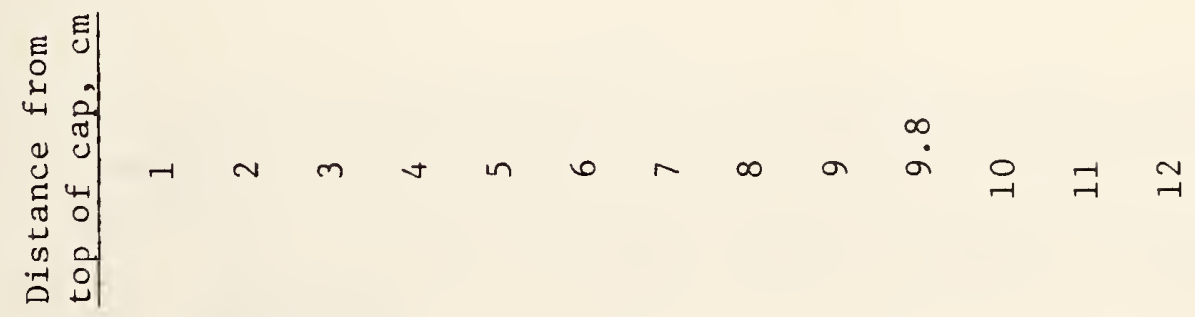



b

Figure 1. Fractures of representative cap screws that failed early in a sequence of cap screw failures. Fractures initiated just under the cap.

a. Fracture surface. Arrows indicate region of fracture initiation.

b. Fracture profile (horizontal at top). 

Figure 2. Fractures of representative cap screws that failed late in a sequence of cap screw failures. Fractures initiated at the root of a thread. $\times 3$

a. Fracture surface. Arrows indicate region of fracture initiation.

b. Fracture profile (at top). 
Figure 3. SEM fractograph of the fatigue portion of the fracture in a type A cap screw.

Figure 4. SEM fractograph of the fatigue portion of the fracture in a type A cap screw. Some apparent striations can be seen. 
Figure 5. Longitudinal sections through two type A cap screws. Etchant: Hot $\mathrm{HCl}$ and $\mathrm{H}_{2} 0,1: 1 \quad \mathrm{X} 11 / 3$

a. Cap screw has been stretched in the region indicated by the brackets. In this region, the diameter of the screw is reduced and the thread pitch is increased.

b. Cap screw exhibits no perceptible deformation. 

a

Figure 6. Longitudinal sections through two cap screws. Etchant: Hot $\mathrm{HCl}$ and $\mathrm{H}_{2} 0,1: 1 \quad \mathrm{X} 11 / 3$
a. Type D cap screw.
b. Type C cap screw. 
Figure 6. Longitudinal sections through two cap screws. Etchant: Hot $\mathrm{HCl}$ and $\mathrm{H}_{2} 0,1: 1 \quad \mathrm{X} 11 / 3$

a. Type D cap screw.

b. Type C cap screw. 
Figure 7. Deeply etched longitudinal section through cap of fractured type A cap screw showing the fracture profile (horizontal at the bottom). The fracture in this screw is just under the base of the cap. Arrows 0 indicate the locations of the regions of fatigue crack initiation. Arrow $\mathrm{C}$ indicates the approximate location of the secondary cracks shown in figure 8 . The unlettered arrows indicate the path of the crack front that, initiated at the right where it deviated from the path of the primary fracture.

Etchant: $5 \%$ nital

Figure 8. Part of the longitudinal section shown in figure 7 with a lighter etch. Two secondary cracks are evident. The approximate location of these cracks is indicated by arrow $C$ in figure 7. Etchant: $2 \%$ picral 

Figure 9. Unetched longitudinal section through type A cap screw exhibiting an inclusion content representative of the cap screws examined.

Figure 10. Longitudinal section through a type $\mathrm{C}$ cap screw showing part of one thread (white area). The dark, thin longitudinal regions adjacent to the surface are areas where inclusions and the surrounding material have been apparently chemically attacked and "eaten out". Unetched 


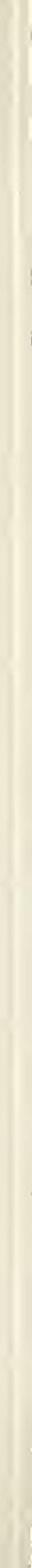


Figure 11. Longitudinal section through a type C cap screw exhibiting representative microstructure which consists primarily of tempered martensite.

Etchant: $2 \%$ picral

X 100

Figure 12. Longitudinal section through an unstretched type A cap screw exhibiting representative microstructure which consists primarily of tempered martensite. Etchant: $2 \%$ picral 

Figure 13. Longitudinal section through stretched type A cap screw. The microstructure consists primarily of tempered martensite. Banding is evident. Etchant: $2 \%$ picral 


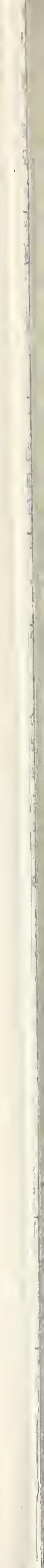


6434 




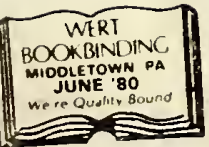


